\title{
인도네시아 쓰나미 긴급구호 및 재건복구 지원사업 종합평가 보고서
}

$\mathrm{KOICA}$ 사업평가실

\section{목차}
I. 개관
II. 주요 결과 분석
III. KOICA의 지원사업 평가

\section{개관}

$\square$ 2004년 12월 발생한 쓰나미 지진해일 피해복구를 위해 국제사회는 전례 없는 대규모 인도적 지 원을 제공하였고, $\mathrm{KOICA}$ 역시 출범 후 최대 규모의 긴급구호 - 재건복구 지원으로 적극 대응함. $\mathrm{KOICA}$ 는 가장 큰 피해를 입은 인도네시아에 물자지원, 봉사단파견 등의 긴급구호와 아체 시범 학교건립, 한-인니 친선병원건립 등 재건복구 사업을 위해 1,720 만 달러를 지원하였음. 쓰나미 지원은 우리나라의 인도적지원 법령, 체제, 매뉴얼의 기틀을 마련하는 계기가 되었음.

$\square$ 본 평가는 $\mathrm{KOICA}$ 인도네시아 쓰나미 긴급구호 - 재건복구 사업의 성과를 살펴보고 우리나라 긴 급구호 수행체계 및 매뉴얼을 종합적으로 평가함으로써 향후 개선방안을 모색하기 위해 추진됨. 인도네시아 재건복구청(BRR)이 2008년 말 활동을 종료하였고 협력단의 재건복구 사업도 2009 년 10월 종료됨에 따라 본 지원 프로그램에 대해 종합적이고 체계적인 평가가 필요한 시점임.

긴급구호 사업의 경우 $\mathrm{OECD} / \mathrm{DAC}$ 8대 평가기준, 재건복구 사업의 5 대 평가기준을 활용하였으 며 긴급구호 수행체제와 매뉴얼은 적절성, 효율성, 연계성을 기준으로 평가함. 
$\square$ 우리나라의 인도적 지원규모는 현재 연 1천만 달러로 $\mathrm{DAC}$ 평균에 크게 못 미치고 있어, 최근 증 가하는 해외재난에 적극적으로 대응하고 국제사회에 기여하기 위해서는 긴급구호 예산의 확대 가 필요함. 2007년 해외긴급구호에 관한 법률 및 시행령을 통해 법적토대를 마련하고 해외재난 복구업무매뉴얼, 해외긴급구호대책 등 지침도 마련하였으나 아직 개선의 여지가 많은 상황임. 자연재해 뿐 아니라 분쟁으로 인한 복합적인 재해가 증가하고 있는 상황에서 법령, 매뉴얼에 '분 쟁' 상황에 대한 지원을 명확히 언급하는 한편, 구체적인 지침을 제시해야함. 매뉴얼의 경우 사 용용도와 재해 구분을 보다 명확히 하는 한편 현장파견인력의 구체적인 활동 지침서가 될 수 있 도록 그룹별, 담당업무별, 절차별로 구체화, 세분화해야함.

긴급구호 효율성을 제고하기 위해서는 $\mathrm{KOICA}$ 의 조정 역할을 강화해야함. $\mathrm{KOICA}$ 의 경우 시행 (implementation)보다는 현장에서 우리 긴급구호대의 수원국 정부, 국제기구, NGO 간의 협력 채널을 구축하고 정보를 수집, 관리, 배포해주는 조정(coordination) 역할을 강화해야 함. 실제 긴급구호 활동의 수행은 중장기적으로 긴급구호 $\mathrm{NGO}$ 와 대한적십자사 등 전문성을 갖춘 기관이 대행할 수 있도록 지원체계를 구축해야 함.

긴급구호 활동, 인력양성에 있어서 민관협력이 강화되어야 함. 소방방재청, 국립의료원 등 정부 측 관련기관간의 협력의 틀이 구축되었으나 $\mathrm{NGO}$ 와 협력이 미흡하여 현장에서 긴급구호 활동 시 정보공유와 조정이 제대로 이루어지지 않고 있음. UNDAC 교육기회 확대 등 긴급구호 전문 인 력 양성을 위한 협력 역시 강화되어야 함.

현지 긴급구호 지원 네트워크에 보다 적극적으로 참여하여 긴급구호 활동에 있어서 국제사회와 의 공조를 강화해야함. 재해 초기 현지 정부와의 협력은 물론 국제사회의 긴급구호 조정시스템 에 적극 참여함으로서 피해국 상황을 신속히 파악하고 역할분담을 통한 지원 중복을 피할 수 있 음. 재해 발생 후 긴급구호 초기단계에서 선발대를 파견하여 정확한 정보수집을 바탕으로 수요 를 파악하는 한편 부문별 전문가 동시 파견을 통해 재건복구, 개발사업과의 연계성을 강화해야 함.

긴급구호 사업의 경우 피해지역 주민의 수요에 적절히 부합하였으나 규모와 방법이 제한적이어 서 전체 파급효과는 크지 않았음.

재건복구 프로젝트로 추진된 아체 시범학교 건립과 한-인니 친선병원 건립 사업 모두, 수원국의 우선순위와 해당지역의 수요에 적절히 부합하였으며 사업기간 및 비용 상 효율성, 경제, 사회적 파급효과 역시 높음. 단, 입찰 및 업체 선정기준의 개선이 필요하고 운영·유지현황, 현지 역량 
을 고려할 때 지속가능성 상의 문제가 발견됨.향후 사업 추진단계별 지역주민의 참여를 유도하고 수혜당사자와 충분한 사전협의를 통한 정확한 수요파악이 필요함. 유지보수 체제를 개선하고 모니 터링 및 사후감독관리를 보다 철저히 하는 한편 기술협력을 통한 지역 역량강화가 필요함.

\section{II. 주요 결과 분석}

그동안 국제사회에서는 쓰나미 지원성과에 대한 다양한 평가가 있었으며, $\mathrm{OECD/DAC}$ 는 인도 적 지원사업 평가 원칙에 따른 모니터링과 평가체제 강화를 강조하고 있음. 특히 인도네시아의 재건복구청(BRR)이 2008년 말 활동을 종료하였고, $\mathrm{KOICA}$ 의 인니 재건복구 지원 역시 종료됨 에 따라 본 지원 프로그램에 대한 종합적이고 체계적인 평가가 필요한 시점임. 국제사회의 지원 에 대해 우리의 긴급구호 - 재건복구사업을 비교분석하고 긴급구호체계와 매뉴얼에 대한 검토를 통해 향후 인도적인 구호활동 및 재건복구사업의 체계성을 확립하고자 함.

$\square$ 이에 따라 본 평가는 긴급구호 - 재건복구사업의 주요 성과 및 여타 공여국의 지원 실태를 비 교 · 평가하여 국제사회의 지원체제하에서의 한국의 역할, $\mathrm{KOICA}$ 의 지원 절차 및 사업 수행체 제를 개선하기 위한 구체적 방안을 검토하고자 함. 특히 KOICA가 추진한 쓰나미 지원사업에 대 한 사후평가와 함께 긴급구호매뉴얼 및 체계에 대한 평가를 통해 그동안의 성과를 정리하고, 앞 으로의 개선방향에 대한 교훈을 도출하고자 함.

\section{KOICA의 지원사업 평가}

\section{가. 긴급구호}

1) 개요

$\square$ 2004년 12월 쓰나미 재해 발생 후 KOICA는 가장 많은 피해를 입은 인도네시아에 2008년까 지 4년 동안 총 1,720 만 달러 지원. 그중에서 긴급구호지원에 전체의 약 $8 \%$ 에 달하는 130 만 달러를 지원하였고, 11 명의 긴급구호봉사단 파견

$\square \mathrm{KOICA}$ 는 재난발생 후 재난구호대책반을 운영(18명)하고, 긴급구호금 및 구호물자 지원, 긴 급구호봉사단 파견 등의 구호업무를 수행. 긴급구호금으로 60 만 달러의 현금 지원

$\square \mathrm{KOICA}$ 현지 사무소 봉사단원 파견. $\mathrm{KOICA}$ 현지사무소 직원 · 봉사단 총 8명이 메단 시 및 아체지역으로 파견되어 피해지역 구호인력, 피해교민 지원. 초기단계에서 현지에서 기존에 
활동하고 있던 봉사단원이 한국에서 파견된 인력에 대한 통역, 안내 등의 역할을 수행하고, 언론기관 취재활동 조정, 메단시 설치 공관 영사사무소 활동 지원. 재해지역 중심으로 팀제 봉사단 수요조사 실시, 보건위생 및 구호품 조사 보고(2005.1.6)

$\square$ 긴급구호봉사단 11 명 파견. 11 명으로 구성된 긴급구호봉사단을 파견하여 의료캠프 운영, 방 역활동, 구호품 배포 등의 활동 수행. 귀국봉사단원, 협력의사·협력요원으로 구성되어 보건 의료, 방역 · 방재 활동을 수행하였음. 반다아체지역의 울레까링 초등학교에서 대피소 난민에 대한 지원활동을 추진, 일일평균 120 명 진료

$\square$ 중기재건복구 계획 수립을 위해 KOICA는 2005년 1월 17일부터 22일까지 정부합동조사단 참가

\section{2) 평가기준별 평가}

\section{가) 타당성}

아체지역은 진원지에 가장 가까워 지진과 쓰나미의 이중 피해를 받아 가장 피해가 극심하 였던 반다아체 지역 선정은 적절. 사망자 128,645 명, 행불자 37,063 명으로 큰 인명피해 가 발생하였으며, 피난민이 50만 명에 달해 긴급구호금 및 구호물자 지원

긴급구호봉사단의 경우 반다아체지역 56 개 초등학교 난민캠프로 조성된 대피소에서 의료 봉사를 추진하고, 진료와 함께 방역활동 및 구호품 배포. 현지봉사단원을 활용하고, 과거 활동경험이 있는 귀국봉사단원 및 의사 등의 파견인력 선정은 봉사단 구성에 있어서 전반 적으로 적절하였음. 난민캠프에 필요한 텐트, 방역기계 등 약품 및 방역물품을 기증하고, 방역활동과 함께 속옷, 아기분, 마스크 등을 구호품을 배포하여 현지수요에 부합

15 일간 활동하면서 굿네이버스, 월드비전, 대한의사협회, 글로벌케어, 국제기아대책기구 등 우리 $\mathrm{NGO}$ 등과 함께 활발한 진료활동과 구호활동 전개. 의료봉사단의 2 주간 체류는 적정했다고 평가되며, 현지 수요에 맞게 활동한 것으로 평가

\section{나) 효율성}

긴급구호봉사단 11 명이 2005.1.12 26일까지 15일간 활동하면서 진료자가 1,090 명에 달하여 짧은 기간 동안 다수를 치료하며 효율적으로 활동하였음. 진료와 함께 현지 의료 여건의 열악성을 보완할 수 있는 방역활동에 중점을 두었으나, 현지 피해규모에 비해 너 
자금지원, 봉사단 파견 및 물자지원을 통해 피해주민 지원을 위한 목표를 전반적으로 달 성하였으나 물자지원의 경우 신속한 수요 파악, 물품수송, 배급 시 어려움이 있었음. 피 해지역에 대한 긴급구호 수요에 대한 정보가 부족하여 초기 활동에 어려움.

$\square$ 난민캠프의 의료활동 지원과 진료, 방역활동이 본격화되면서 현지주민들로부터 호응을 받았고 의료봉사단으로서 긴급구호활동은 현지수요에 적정한 의료 활동과 방역활동을 수 행함.

\section{다) 파급효과}

의료봉사단으로서 난민캠프 내 의료지원과 방역 활동, 기본적인 생필품을 배포하여 대피 소 난민들의 보건 및 의료 개선에 기여함.

현지 의료체제 지원 및 복구까지 긴급한 의료지원을 달성하여 아체지역 주민들의 건강 및 보건 개선이라는 상위목표에 부분적으로 기여함.

\section{라) 지속가능성}

정부합동조사단 및 현지실태 보고 등을 토대로 한 · 인니 친선병원 건립사업 등 후속사업 으로 연계되어 아체지역 보건 및 의료지원 체제 강화에 기여함. 단, 현지지역주민의 참여 등을 통한 역량강화 항목은 미흡함.

$\square$ 당시 $\mathrm{KOICA}$ 기획조정팀이 정부조사단 보고 및 공관 실태보고서를 토대로 재건 복구지원 사업 제안서 작성(2005.2), 인도네시아 지원패키지 마련(2005.3). 재건복구청(BRR) 설 립 후 아체 주 재건복구 사업 $\mathrm{MOU}$ 체결 (6개 사업, 1,52 만 달러) 긴급구호사업이 재건 복구사업에 연계되도록 노력

\section{마) 일관성}

정책적 일관성이라는 측면에서 국제사회의 인도적 지원을 위해 지원체제가 구축되고, 아 체지역의 반정부 활동으로 초기 활동에 어려움이 있었으나, 정부와 평화합의가 체결됨.

반다아체 지역의 어업산업이 괴멸하여 대부분의 노동력이 실업상태에 빠지고, 고아와 미 망인들이 다수로 취약계층에 대한 고려가 필요했으나, 이에 대한 지원책 미비 


\section{바) 안전성}

$\square$ 봉사단의 경우 쓰나미 발생 직후에는 피해국에 파견되어있던 봉사단원의 인명피해 및 부 상자 파악에 주력하였으며 상황파악이 된 이후 차츰 현지 긴급구호와 재건복구 지원을 위 한 봉사단 활동에 초점이 맞추어짐. 당시에는 대규모 해외재난 발생 등 비상상황시의 긴급 연락망, 후송 등의 체계가 갖추어지지 않아 여러모로 혼란이 많았던 것으로 평가됨.

\section{나. 재건복구}

1) 한-인니 친선병원 건립사업

가) 개요

(1) 사업금액 및 기간

$\square$ 총 사업금액 : 3,700 백만 원 (3,700 천 달러)/ 사업기간 : 2006년 2007년 2년간

표1. 친선병원 사업 연도별 예산집행계획안

(단위 : 천 달러)

\begin{tabular}{|c|c|}
\hline 구 분 & 계 \\
\hline 설계 & 100 \\
\hline 감리 & 120 \\
\hline 시공 & 2,000 \\
\hline 연수생초청 훈련 & 85 \\
\hline 기자재 공여 & 1,000 \\
\hline 전문가파견 & 95 \\
\hline 기타 (사전조사, 의료기술 자문 등) & 300 \\
\hline 합계 & 3,700 \\
\hline
\end{tabular}

자료:KOICA 인도네시아 아체 병원건립사업 기본계획안

(2) 항목별 평가 내용

표2. 친선병원 평가기준 및 항목

\begin{tabular}{|c|l|}
\hline 평가기준 & \multicolumn{2}{|c|}{ 평가항목 } \\
\hline 적절성 & - 수원국 개발정책 $-\mathrm{MDGS}-$ 사업지역 - 사업대상지의 의료수요 \\
\hline 효율성 & - 사업실시기간 사업비용 잉찰 및 조달 과정 \\
\hline 효과성 & - 당초 사업목표 달성여부 $\quad$ 사업운영현황 \\
\hline 파급효과 & - 경제 · 사회적 파급효과 $\quad-$ 기술이전 파급효과 \\
\hline 지속가능성 & - 운영 $\cdot$ 유지 현황 및 체 - 지역의 의료수요전 - 재정 $\cdot$ 행정 $\cdot$ 인력 요건 \\
\hline 연계성 및 조정 & $-\mathrm{LRRD}-$ 아체주정부, 수원기관, 타공여국과의 협력 및 조정, 사업의 중복여부 \\
\hline
\end{tabular}


※ 위의 평가기준과 더불어 병원의 특수성을 반영한 아래와 같은 기준에 근거하여 평가가 이루어졌음. ${ }^{11}$

\begin{tabular}{|l|llll|}
\hline \multicolumn{1}{|c|}{ 평가대상 } & \multicolumn{4}{c|}{ 평가항목 } \\
\hline 의료의 질적 수준 & - 환자의 안전과 편의 & - 감염관리 & - 시설환경 관리 & - 환자진료 \\
\hline 인력관리 & - 인력의 충족성 & - 직원교육 & & \\
\hline 병원운영 & - 경영관리 & 실 & 및 환경 관리 & - 진료실적 \\
\hline
\end{tabular}

(3) 종합의견

전체적으로 친선병원 사업은 소수의 개선사항이 있으나 적절성, 효율성, 효과성 및 파급 효과 측면에서는 전반적으로 우수한 것으로 평가됨. 다만, 사업의 지속가능성 측면에서 개선사항이 다수 발견되었으며, 추후 개발사업으로의 연장을 통해 LRRD 차원에서의 연 계성을 확보하는 작업이 필요할 것으로 여겨짐.

\section{표 3. 친선병원 사업의 종합평가내용}

\begin{tabular}{|c|c|}
\hline 평가기준 & 평가내용 \\
\hline 적절성 & $\begin{array}{l}\text { 수원국 개발정책 및 MDGs와의 부합여부, 사업지역의 적정성을 기준으로 판단할 때, 이 사업은 } \\
\text { 현지의 수요와 상황을 매우 적절히 반영 }\end{array}$ \\
\hline 효율성 & $\begin{array}{l}\text { 사업실시기간과 사업비용을 기준으로 사업은 효율적으로 추진되었으나, 입찰 및 업체선정에 있 } \\
\text { 어 개선이 필요 }\end{array}$ \\
\hline 효과성 & $\begin{array}{l}\text { 사업은 당초 계획에 따라 병원이 완공되었으며, 병원 운영현황, 기자재 활용현황에 대한 조사결 } \\
\text { 과 대체로 사업목표를 달성하였으나 의료의 질적 수준 향상을 위한 군 당국의 노력 및 한국의 } \\
\text { 지원검토가 필요 }\end{array}$ \\
\hline 파급효과 & $\begin{array}{l}\text { 경제 · 사회적 파급효과, 기술이전 등 파급효과를 기준으로 평가했을 때 전반적으로 높은 파급 } \\
\text { 효과 }\end{array}$ \\
\hline 지속가능성 & $\begin{array}{l}\text { 운영 · 유지 현황 및 체계, 지역의 의료수요전망, 재정·행정·인력 요건을 기준으로 평가하였 } \\
\text { 을 때 다소 낮은 지속가능성 }\end{array}$ \\
\hline $\begin{array}{l}\text { 연계성 } \\
\text { 및 조정 }\end{array}$ & $\begin{array}{l}\text { 긴급구호-재건복구 개발사업의 연계성을 바탕으로 추후 기술협력을 위주로 한 지역 의료역량 } \\
\text { 강화를 위한 사업의 확대가 필요하며 수혜당사국과의 보다 적극적인 조정 및 협력이 요구됨. }\end{array}$ \\
\hline
\end{tabular}

\section{2) 아체 시범학교 건립사업}

가) 개요

(1) 사업금액 및 기간

총 사업금액 : 5,760 백만 원 (5,400 천 달러)/ 사업기간 : 2006년 2007년 2년간

1) 이 평가기준은 현재 한국에서 통용되고 있는 의료기관 평가지침서를 참고로 사업대상 병원의 특수성과 관련 자료의 습 득 가능성 등을 감안하여 평가팀에서 재작성 하였으며, 친선병원 자체의 운영성과를 평가하는 것이 아니라 KOICA의 병 원사업에 대한 성과를 평가하는 것이 본 평가의 주목적이므로 이와 연관성이 높은 항목만을 적용하였음. 이 과정에서는 현직 의료전문가 및 의료평가 참여경험이 있는 의료인의 자문을 참고함. 
표 4. 시범학교 예산집행 내역

\begin{tabular}{|c|l|}
\hline 구분 & \multicolumn{1}{|c|}{ 내역 } \\
\hline 기본 $\cdot$ 실시설계 및 감리 & 설계감리계약 $(184,000,000$ 원 $)$ \\
\hline 학교건축 & 시공계약 $(3,995,276,000$ 원 $)$ \\
\hline 연수생초청 훈련 & 90 천 달러 (16명, $2007.11 .1-21)$ \\
\hline 기자재 공여 & $\begin{array}{l}1,100 \text { 천 달러 (물품공급계약 수정체결 } 1,051,022,638 \text { 원, } \\
\text { 스쿨버스 현지구매 \$221,000) }\end{array}$ \\
\hline 기타 사전조사 등 & $\begin{array}{l}\text { 65천 달러 (사전조사단, 사업현장점검 및 모니터링, 사업 } \\
\text { 협의결과 등 보고서 발간 등) }\end{array}$ \\
\hline 합계 & 5,400 천 달러 \\
\hline \multicolumn{2}{|l}{} \\
\hline
\end{tabular}

출처: KOICA 종료보고서

(2) 사업목표

교육시설 지원을 통한 인적자원개발 도모, 사업목표 : 현대적 학교시설 건축을 통한 교육 환경 개선

(3) 사업내용

학교신축 및 기자재 공여:나간라야지역 4 개교(유치원 1 , 초등학교 1 , 중학교 1 , 고등학교 1) 아체바랏다야지역 3 개교(초등학교 1 , 중학교 1 , 고등학교 1), 학교비품 및 교육기자재

연수생 초청 사업: 관계자 대상으로 2007년 11월 3주간 실시

\section{나) 항목별 평가 내용}

표 5. 시범학교 평가기준 및 항목

\begin{tabular}{|c|c|c|c|}
\hline 평가기준 & \multicolumn{3}{|c|}{ 평가내용 } \\
\hline 적절성 & - 수원국 개발정책 & - 사업지역 & - 사업대상지의 교육수요 \\
\hline 효율성 & - 사업실시기간 & - 사업비용 & 달 과정 \\
\hline 효과성 & - 당초 사업목표 달성 & - 사업운영현황 & \\
\hline 파급효과 & - 경제 · 사회적 파급효과 & - 기술이전의 파급효 & \\
\hline 지속가능성 & - 운영 · 유지 현황 및 체겨 & | 지역의 교육수요전망 & - 재정 · 행정 · 인력 요건 \\
\hline 연계성 및 조정 & - LRRD $\quad-$ 아체 & 주정부, 수원기관, 타공여국과의 & 및 조정, 사업의 중복여부 \\
\hline
\end{tabular}

\section{다) 종합평가}

전체적으로 시범학교 사업은 소수의 개선사항이 있으나 적절성, 효율성, 효과성 및 파급 효과 측면에서는 전반적으로 우수한 것으로 평가됨. 다만, 사업의 지속가능성 측면에서 개 선사항이 다수 발견되었으며, 추후 개발사업으로의 연장을 통해 LRRD 차원에서의 연계 
성을 확보하는 작업이 필요할 것으로 여겨짐.

\section{표 6. 시범학교 사업의 종합평가내용}

\begin{tabular}{|c|c|}
\hline 평가기준 & 평가내용 \\
\hline 적절성 & $\begin{array}{l}\text { 수원국 개발정책 및 MDGs와의 부합여부, 사업지역의 적정성 및 사업대상지역의 교육수요를 기 } \\
\text { 준으로 판단할 때, 이 사업은 현지의 수요와 상황을 매우 적절히 반영 }\end{array}$ \\
\hline 효율성 & $\begin{array}{l}\text { 사업실시기간과 사업비용을 기준으로 사업은 효율적으로 추진되었으나, 입찰 및 업체선정에 있 } \\
\text { 어 개선이 필요 }\end{array}$ \\
\hline 효과성 & $\begin{array}{l}\text { 당초 계획에 따라 학교가 완공되었으며, 학교 운영현황, 기자재 활용현황에 대한 조사결과 현대 } \\
\text { 적 학교시설 건축을 통한 교육환경 개선 사업목표를 전반적으로 달성 }\end{array}$ \\
\hline 파급효과 & $\begin{array}{l}\text { 경제· 사회적 파급효과, 기술이전의 파급효과를 기준으로 평가했을 때 전반적으로 높은 파급효 } \\
\text { 과 }\end{array}$ \\
\hline 지속가능성 & $\begin{array}{l}\text { 운영 · 유지 현황 및 체계, 지역의 교육수요전망, 재정·행정 · 인력을 기준으로 평가하였을 때 } \\
\text { 다소 낮은 지속가능성 }\end{array}$ \\
\hline $\begin{array}{l}\text { 연계성 } \\
\text { 및 조정 }\end{array}$ & $\begin{array}{l}\text { 긴급구호-재건복구 개발사업의 연계성을 바탕으로 추후 기술협력을 위주로 한 지역 교육역량 } \\
\text { 강화를 위한 사업의 확대가 필요하며 수혜당사국과의 보다 적극적인 조정 및 협력이 필요 }\end{array}$ \\
\hline
\end{tabular}

\section{IV. 종합 제언}

$\square$ 남아시아 쓰나미 지진해일 피해복구를 위해 국제사회는 전례 없는 대규모 인도적 지원을 제공하 였고, $\mathrm{KOICA}$ 는 가장 큰 피해를 입은 인도네시아에 긴급구호와 재건복구 사업을 통해 다양한 지 원을 추진하였음.

$\square$ 본 평가는 $\mathrm{KOICA}$ 인도네시아 쓰나미 긴급구호 - 재건복구 사업의 성과를 살펴보고, 우리나라 긴급구호 수행체계 및 매뉴얼을 종합적으로 평가하였으며, 다음과 같은 개선조치와 향후 중장기 과제를 제안함. 
표 7. 개선조치 및 중장기 과제(요약)

\begin{tabular}{|c|c|c|c|}
\hline 구분 & 교훈 & 개선조치(단기) & 고려사항 및 중장기 과제 \\
\hline \multirow{5}{*}{$\begin{array}{l}\text { 긴급 } \\
\text { 구호 }\end{array}$} & $\begin{array}{l}\text { 긴급구호 역량강화 및 } \\
\text { KOICA 역할의 재정립 }\end{array}$ & $\begin{array}{l}\text { 현지에서 KOICA의 조정 및 협력 기능 } \\
\text { 강화 } \\
\text { 민간 } \mathrm{NGO} \text { 와 협조체제 구축 }\end{array}$ & $\begin{array}{l}\text { 긴급구호 전문인력 양성, 전문 NGO 지정, } \\
\text { 적십자 지원 } \\
\text { 긴급구호 예산확대, 지원방식 다양화 }\end{array}$ \\
\hline & $\begin{array}{l}\text { 국제긴급원조 조정 및 } \\
\text { 협조체제 참여기반 확대 }\end{array}$ & $\begin{array}{l}\cdot \text { 유엔OCHA 조정시스템 참여 강화 } \\
\text { · 구조팀, 의료팀 입국시 OSOCC 등록 } \\
\text { · 현장 정보 신속하게 전달, 민간 NGO } \\
\text { 와 공유 } \\
\text { · 국제기관과 협조가능한 긴급구호 전 } \\
\text { 문가 파견 }\end{array}$ & $\begin{array}{l}\text { INSARAG, UNDAC, OSOCC 참여를 통해 } \\
\text { 정보 및 협력 기반 강화 } \\
\text { 국제기관과의 협조체제를 강화하여 KOICA } \\
\text { 의 Control tower 역할 환대 } \\
\text { 군수송기 및 보급선 파견에 국제적 권고 } \\
\text { 및 신중한 내부 검토 }\end{array}$ \\
\hline & $\begin{array}{l}\text { 현지의 긴급구호 여건 } \\
\text { 및 재건복구 체계에 대 } \\
\text { 한 이해 제고 }\end{array}$ & $\begin{array}{l}\text { 초기 정보 수집에 중점, 재해발생 후 } \\
\text { 선발대 신속파견 및 현지수요 파악 } \\
\text {. 초기단계에 재해 조사팀 파견 }\end{array}$ & $\begin{array}{l}\text { · 재해빈발국 법령, 지원체계 사전교육 } \\
\text { · 민관협력 정보공유·상시 대비체제 구축 }\end{array}$ \\
\hline & $\begin{array}{l}\text { 긴급구호 이후 재건에 } \\
\text { 대한 체계적 지원 필요 }\end{array}$ & $\begin{array}{l}\text {. 긴급구호 초기단계 부문별 전문가파 } \\
\text { 견 통한 재건복구 수요조사 } \\
\text { · 재건복구 이후 개발 사업발굴 : 지역 } \\
\text { 역량강화 및 생계수단지원 }\end{array}$ & $\begin{array}{l}\cdot \text { 재해와 분쟁 피해의 복합성 고려 } \\
\text { - DRR 강화 } \\
\text { - 재해빈발국 CAS에 인도적 지원 방안 을 } \\
\text { 사전에 검토하여 반영 }\end{array}$ \\
\hline & 현지 취약계층 고려 & $\begin{array}{l}\text { 긴급구호 및 재건부구사업에 계획단 } \\
\text { 계부터 취약계층을 고려하고, 참여 기 } \\
\text { 반 확대 }\end{array}$ & $\begin{array}{l}\text { - 매뉴얼에 젠더 · 환경 · 노약자 · 아동 · 인 } \\
\text { 권 고려 강화 } \\
\text { - 여성에 대한 지원대책 마련 }\end{array}$ \\
\hline \multirow{5}{*}{$\begin{array}{l}\text { 재건 } \\
\text { 복구 }\end{array}$} & $\begin{array}{l}\text { 지역주민의 참여확대 및 } \\
\text { 수혜자중심 사업설계 }\end{array}$ & $\begin{array}{l}\text { · 사업추진단계별 지역주민 참여 활성 } \\
\text { 화 }\end{array}$ & $\begin{array}{l}\text { 인프라 구축 외 기술전수 강화 } \\
\text { 지방정부 및 지역사회 역량강화, 제도정비, } \\
\text { 인력훈련 지원 확충 }\end{array}$ \\
\hline & $\begin{array}{l}\text { 현지조달 확대 및 유지 } \\
\text { 보수 체제 개선 }\end{array}$ & $\begin{array}{l}\cdot \text { 사후관리 및 유지보수체제 개선 } \\
\text { · 설계· 시공· 감리 과정 현지업체의 } \\
\text { 전문성 활용 및 참여 확대 }\end{array}$ & $\begin{array}{l}\text { 업체 선정시 자격심사실시 의무화 } \\
\text { 현지조달 및 언타이드 확대 } \\
\text { 재해관련 전문업체 참여 유도 }\end{array}$ \\
\hline & $\begin{array}{l}\text { 모니터링 및 사후관리 } \\
\text { 강화 }\end{array}$ & $\begin{array}{l}\cdot \text { 프로ㅈㅔㅔㅌㅡ 관리 및 감독 강화 : 업체 } \\
\text { 계약이행 여부 및 지불조건 강화 } \\
\cdot \text { 사업시행, 모니터링, 평가 시 지역의 } \\
\text { 해당분야 전문가 참여 확대 }\end{array}$ & $\begin{array}{l}\text { 유지보수 및 사후관리 체제 강화 } \\
\text { 결과위주 관리 강화를 위한 모니터링 확대 }\end{array}$ \\
\hline & $\begin{array}{l}\text { 지속가능성 강화 및 후 } \\
\text { 속사업추진 }\end{array}$ & $\begin{array}{l}\text { - 개별사업에서 다분야 지원방식 및 적 } \\
\text { 정 지원부문, 지역 내 수요에 대한 체 } \\
\text { 계적 조사 실시 }\end{array}$ & $\begin{array}{l}\text { - 프로그램식 방식의 종합적 부문별, 지역별 } \\
\text { 지원방안 및 지속가능성 제고 } \\
\text { · 재해대비 역량강화 및 생계구축사업 지원 }\end{array}$ \\
\hline & $\begin{array}{l}\text { 파트너십 및 협력관계 } \\
\text { 확대 }\end{array}$ & $\begin{array}{l}\cdot \text { 사업실시주체 간 조정 · 협력 강화 } \\
\text { · 사업단계별 NGO 참여 활성화 }\end{array}$ & $\begin{array}{l}\text { ·PPP 프로그램 도입 } \\
\text { · NGO 지원 민관협력 플랫폼 구축 } \\
\end{array}$ \\
\hline \multirow{4}{*}{$\begin{array}{l}\text { 매 } \\
\text { 뉴 } \\
\text { 얼 }\end{array}$} & $\begin{array}{l}\text { 재해의 구분 기준 및 재 } \\
\text { 해주권 }\end{array}$ & $\begin{array}{l}\text { 재해규모 및 대응범위 관련 세부기준 } \\
\text { 마련 }\end{array}$ & $\begin{array}{l}\text { 분쟁, 취약국 지원에 대한 지침 명확화(법 } \\
\text { 률, 매뉴얼) } \\
\text { 재해주권 및 인도적 개입에 대한 고려 }\end{array}$ \\
\hline & $\begin{array}{l}\text { 세부적이고 구체적인 매 } \\
\text { 뉴얼 필요 }\end{array}$ & $\begin{array}{l}\text { · 파견절차별 세부지침 강화 : 현장중심 } \\
\text { 의 세부지침 마련 } \\
\text { · 선발대, 전문가조사단 활동지침 } \\
\text { · 긴급구호 관련 PDM 및 결과보고서 } \\
\text { 작성 의무규정 명시 }\end{array}$ & $\begin{array}{l}\text { 구조대, 의료팀, 전문가 조사팀 등 파견그 } \\
\text { 룹별로 세분화된 매뉴얼 마련 } \\
\text { 재해별 특성에 따라 차별화된 지침과 규정 } \\
\text { 마련 } \\
\text { 긴급구호활동에 대한 평가지침 및 항목 마 } \\
\text { 련 }\end{array}$ \\
\hline & $\begin{array}{l}\text { 민간부문과의 협력 체제 } \\
\text { 강화규정 도입 }\end{array}$ & $\begin{array}{l}\text { - 민간부문과의 네트워크 강화 : 전문가 } \\
\text { 교육 및 시뮬레이션 공동 추진 }\end{array}$ & $\begin{array}{l}\text { 민간부문과의 파트너십 항목 미비로 구체 } \\
\text { 적 언급 명시 필요 } \\
\text { 현지사무소 역할 강화 및 매뉴얼 상 명시 }\end{array}$ \\
\hline & $\begin{array}{l}\text { 긴급구호 전문인력 양성 } \\
\text { 규정 강화 }\end{array}$ & $\begin{array}{l}\text { Sphere Project 교육 상시개설 및 참 } \\
\text { 여대상 확대 } \\
\text { - UNHCR eCenter 교육 참여지원 } \\
\text {. UNDAC 교육대상 확대 }\end{array}$ & $\begin{array}{l}\text { - UNDAC 요원을 } 10 \text { 인 이상으로 확대, 파견 } \\
\text { 활성화 제도마련 }\end{array}$ \\
\hline
\end{tabular}

